\title{
Revealing and Dismantling Ideological Media Texts
}

\author{
Mahmudah \\ Universitas Negeri Makassar \\ Faculty of Languages and Literature \\ Makassar, Indonesia \\ Mahmudah.mahfud@unm.ac.id
}

\begin{abstract}
The purpose of this study is to reveal and dismantle ideology on media texts based on the form of exclusion and inclusion. The research is a qualitative study that assessed using critical discourse analysis based on Theo Van Leeuwen perspective. The data in this study is the verbal (e.g.words, phrases, clauses, and sentences) and nonverbal (e.g.context unbiased opinions about current events discussion, reviews about the issues that are loaded, and the subjective mind editor). Sources of data obtained from headlines in Kompas and Fajar Newspaper published in March and April 2015. The data collection technique used is the technique of documentation, reading technique, and taking notes technique. The results showed that the disclosure and dismantling ideological media texts using the two strategies, namely: 1) the exclusion in the form of passive and noun and 2) the inclusion in the form of differentiation, abstraction, categorization, and associations.
\end{abstract}

Keywords-Revealing; dismantling; ideological media text

\section{INTRODUCTION}

Performing the reality through the media is a demand in writing news that cannot be separated with the use of coherent and clear language. The use of language by the parties involved in a particular event can be expressed equally. However, news can lead the reader to form public opinion in defiance of the interests of society [1]. The main function of the news in the formation of opinion arises or falls expectations through their reports of events. Public opinion has its characteristics, namely content, direction, and intensity, these characteristics concerning public opinion about political figures, usually government officials and candidates of officials, parties, events. Public opinion is formed from personal opinion, and then becomes a public opinion and has a long survival time.

The news is always vigorous and repeatedly broadcast by the press, for the community taken from what is broadcasted without the filter. Moreover today, people are experiencing turmoil regarding trust in the government. The only one information axis is easily accessible to the entire community, which is connected to the public with the condition of the government, the current state of the country.

Marx behind the critical thinking states that the media is the place where ideological struggles take place. Habermas as one of the thinkers of this school asserted that the media is a reality in which the dominant ideology in this case of capitalism is spread to public and forms what he calls false consciousness [2]. This awareness is the consciousness that is

\author{
Nurhusna \\ Universitas Negeri Makassar \\ Faculty of Languages and Literature \\ Makassar, Indonesia
}

formed by the interests of the dominant group so that their interests are maintained.

Marcuse, the critical thinker, also reveals the condition above in his discussion of the one-dimensional man. For him, the one-dimensional human is the man who in his life experiences the obscurity of two contradictions that should always be understood. The primary contradiction is the presence of dominant groups who always try to master or subordinate other groups. In one-dimensional human life, the differences are obscured so that a human being as an individual is unaware of his existence in these two contradictions. The absence of individual awareness makes them easy to master because of the loss of their consciousness as a group of oppressed [3].

The picturer and the media interaction to public become so essential and always to be criticized [4]-[6]. The media in practice is the space where ideology is fought for a place in the minds of audiences. People who fight in the life of the media becomes important to see their power. People can exploit their power in influencing the media. The media is not just a channel of communication but also as an institution that has become part of society with the ideological battle in it. Why is media and community interaction so important? Media as an institution is present and moves in the public sphere. Therefore, the existence of the media should not be separated from the public interest itself [3], [7]. Any interest outside the public, especially the dominant can distort the communication process so that the public is eliminated from self-interest and created a false consciousness.

Therefore, we need a strategy to dismantle the ideology hidden in a text through critical discourse analysis. According to Theo van Leeuwen that there are strategies that can be used to detect and investigate how actors (someone / social group) marginalized position in a text (exclusion) [8]. Meanwhile, there is the dominant group in control in interpreting an event and use. The low position groups tended to invariably as objects of meaning and described terrible (inclusion).

\section{METHOD}

This research is a qualitative study that assessed using discourse analysis by Theo van Leeuwen [9]. The data in this study is a word, phrase, clause, and sentence containing exclusion and inclusion. Sources of data obtained from headlines in Kompas and Fajar Newspaper are published in March and April 2015. The data collection technique used documentation, reading, and note-taking The data analysis 
technique begins with data identification, data reduction, data presentation, and conclusion.

\section{RESULTS AND DISCUSSION}

\section{A. Exclusion}

Exclusion is a process for issuing specific groups or social actors who became the central issue that can transform public understanding of an issue and legitimize the position of understanding [10]. The forms of exclusion found in this study as described below.

1) Passive: Selection of the passive voice has obscured who bring the case to the Attorney General. Delegated "Word" means negative image to the institutions Commission. Corruption Watch Commission with full authority on corruption case seems weak in dealing with such cases. The attention of the mass media presented more emphasis on the Commission decision in setting the Commissioner-General Budi Gunawan as suspects; therefore, the case gets the attention of the pretrial judge. The strategy resulted in the article language becomes uncritical by the absence of the actor or performer. In contrast the used active form would put the position of the actors as a subject at the center of attention of the reader. Making sentence passive suggests that the minister inspected and detained by Corruption Watch Commission is not the object or point the reader's attention in order that they can be saved by the mass media. Finally, the reader's perception of the performance of the Commission raised doubts.

2) Noun: The use of language through nominalization strategy is similar to the passive exclusion process, namely the removal of the figure of the perpetrator or actor. The noun form is necessarily a process of changing meaningful action verb/noun activities into meaningful events. The review is categorized as (noun) was a reexamination to be conducted by the Commission. These expressions give the perception to the reader that the Commission does not have the energy anymore against Budi Gunawan case so that the Commission considered lost to the Chief of Police. This suggests the Commission no longer perform their duties correctly.

Word of "resistance" (actions/events against) is a process of exclusion as a focal point in the sentence that gives the perception to the reader about the refusal of some parties to the presence of the Commission as the most influential institution in combating corruption. This can be seen that noun take away the subject. In this case, the person/party opposed the presence of the Commission.

\section{B. Inclusion}

Inclusion is a strategy of discourse while doing something, someone, or a group shown in the text [11].

1) Differentiation-unity: Differentiation and unity inclusion technique is a technique of discourse contrasted heterogeneous party presence and the subordinate. By contrasting, one group would be the minor group and the other group would be the dominant and privileged position. The inclusion strategy is in the form of differentiation that shows two different things are compared. The CWC image is so horrific as compared with other groups, namely SC. CWC group represented as subordinate parties for their verdict that has been set by the CWC regarding the determination of the suspect Budi Gunawan, but must be reviewed by the Supreme Court. That is why the CWC decision are marginalized due to their weakness as a state institution with the task of combating corruption. It showed that the existence of the CWC as a state institution as if they want to be removed by multiple groups. This would give a weakening and a negative image of the performance of the CWC.

2) Objectivities-Abstraction: Objectivities-abstraction is a technique related inclusion on the question of whether information about an event or social actors appears to give concrete instructions or shown is an abstraction. Presentation and many words there are to apply the techniques of abstraction. An event that actually is quantitatively in number with abstraction communicated as numerous. In this case, the decision will have an impact on the quality of Commission as a state institution. Said there and many refer to the parties to agree and disagree on a verdict "Sarpin", means the quantity agreed less compared with those who disagree. This, to illustrate that many are unhappy with the decision of the Commission of the determination of the suspect so that the Commission is no longer an objective in determining a person becomes a suspect and is considered a weak state institutions.

3) Noun-category: In news about the actor (person or social group) or about an issue is elected if the actor is shown as it is, or what is called the category of social actors. The emphasize on category of Former Minister of Religion and a former member of the House of Representatives Commission VII associate into the minds of the audience that the two suspects had the same status as Budi Gunawan, are not state officials or law enforcement authorities so that the determination of the two of them by the Commission as a suspect invalid. Therefore, they filed a pretrial petition for establishing themselves as a suspect.

4) Association-dissociation: Association-Dissociation is the inclusion technique related to the question whether a party actor displayed alone or was connected with another larger group. It is a process that often happens and without realizing it. Association showed understanding when in the text, social actors linked to an association or a larger group, where the actor was. Through this technique, the generalization effects occur. This is evident from the following sentence fragment. CWC as an institution reforms biological children now only rely on the strength of civil society as a protector of the Commission when the nation's political elite's commitment to the eradication of corruption agenda is questionable. Provide an overview to the reader that the CWC institution is an institution that is a child of the reform. The phrase implies reforming child of the reader's perception that the Commission as a state institution in the field of combating corruption has 
weaknesses because they were born in a period of reform. In the sense that the Commission is motivated by a period of reform, of course, the weakness of the reform be weakening of the Commission as an institution fighting corruption.

\section{CONCLUSION}

This study reveals and dismantles ideological media texts with exclusion and inclusion. Exclusion is a process for issuing specific groups or social actors who became the central issue that can transform public understanding of an issue and legitimize the position of understanding. The forms of exclusion found in this study passive and noun. Inclusion is a strategy of discourse while doing something, someone, or a group shown in the text consists of differentiation-unity, objectivities-abstraction, noun-category, and associationdissociation.

\section{REFERENCES}

[1] K. Krippendorff, Content analysis: An introduction to its methodology. Sage, 2004.

[2] J. Habermas, Between facts and norms: Contributions to a discourse theory of law and democracy. Mit Press, 1996.

[3] H. Marcuse, The aesthetic dimension: Toward a critique of Marxist aesthetics. Beacon Press, 2014.

[4] C. J. Calhoun, Habermas and the public sphere. MIT press, 1992.

[5] D. Kellner, "Habermas, the public sphere, and democracy," in Re-imagining public space, Springer, 2014, pp. 19-43.

[6] J. Habermas, The structural transformation of the public sphere: An inquiry into a category of bourgeois society. MIT press, 1991.

[7] J. Habermas, "Religion in the public sphere," Eur. J. Philos., vol. 14, no. 1, pp. 1-25, 2006.

[8] T. Van Leeuwen, Discourse and practice: New tools for critical discourse analysis. Oxford University Press, 2008.

[9] T. Van Leeuwen, "Critical discourse analysis," Int. Encycl. Lang. Soc. Interact., 2009.

[10] T. Van Leeuwen, "The representation of social actors," Texts Pract. Readings Crit. discourse Anal., vol. 1, pp. 32-70, 1996.

[11] L. Hempenius, J. P. J. Slaets, M. A. M. Boelens, D. Z. B. van Asselt, G. H. de Bock, T. Wiggers, and B. L. van Leeuwen, "Inclusion of frail elderly patients in clinical trials: solutions to the problems," J. Geriatr. Oncol., vol. 4, no. 1, pp. 26-31, 2013. 